\title{
LOOKING AT ASIA PACIFIC...
}

Frans Sluifer

\section{Under the title "the poor and the rich" The Economist from May 25", 1996 sought to explain why some countries are richer than others. Here are some important conclusions:}

\section{Differences between countries exist not because of a lack of resources but because of the inability to use existing resources efficiently and effectively;}

\section{Most economists agree that the most important reasons for the economic growth in Asia are "the broader policies encouraging education, the opening of the economy to foreign fechnologies, the promoting of trade and taxes kept low".}

Welcome to Asia where I have been living now for almost a year, after nearly nine years in Brazil. Here are some observations I want to make about the economic growth in this region. I hope that this will help you, to realise that there are many opportunities for Brazilian Businesses outside the traditional triangle - Latin America - USA - Europe.

Asia Pacific encompasses all countries from the Indian subcontinent eastwards, including China and Japan. Australia and New Zealand are also part of this description.

Most of these countries participate in various international regional associations, like ASEAN, which are set up to foster economic growth in the region or to build a political counterweight against China. Lately, the Americans have discovered their "Pacifc identity" and so has Australia.

This "Pacific" commonality has led to the establishment of APEC (Asia Pacific Economic Cooperation) aiming at free and open trade and investment amongst its 18 members, which includes the USA. So far, ten other countries, including four Latin American ones, are, unsuccessfully, knocking on the door.

The world is starting to discover Asia Pacific and for good reasons: the region houses about $60 \%$ of the world population and they all live in very fast growing market economies. Actually, half of the growth of the world economy happens in
Asia Pacific. The region is on its way to become very affluent and will become the largest market in any sector of the world.

The countries in the region are in different stages of development, but by large, they follow the same policies: open market, investments in education and infrastructure and, finally, policies which are interesting for business, transparent and stable. And highly competitive, because governments realise that there is not a great deal of feelings in the flow of capital and technology.

Each and every country in this region deserves a book, if not a library. And many indeed have been written. I would like to make a few brief observations about two countries, both on either side of the scale: Singapore and China.

Singapore, not so long ago an "entrepôt economy", transformed itself into a very modern state in a little more than a generation. Actually, it is doing so well that, today, $90 \%$ of all families own their house or apartment. It also has the best infrastructure in the region and a per capita income of over $\mathrm{U} \$ 25,000$ per year.

Asiaweek, one of the leading magazines in the region, publishes a number of key factors for success. The most important are: strong government, long term planning, foreign investment, clean administration, emphasis on education, law and order, a non "welfare state" and sensitivity to other cultures 
in a multi-racial society.

For Business, there is the Economic Development Board which helps investors to find their way in Singapore. It also helps them to set up their operations and that includes assistance to obtain the best fiscal advantages or maximum incentives.

Singapore is corruption free, but the Prime Minister earns an annual salary of US $\$ 600,000$. Likewise, senior officers of the government have high salaries and very often receive big bonuses. "Paying government staff well is cheaper than allowing for corruption".

Set off as a centre for cheap labour at the beginning of its development, today the country has become a finance centre, a technological centre (that includes a lot of R. D.) and regional headquarters of many international companies. Incentives have greatly helped but so have the elements of policy I mentioned earlier.

And the "cheaper labour industries...". Actually the Singaporeans are relocating them in special industrial zones, under joint administration, in Indonesia, Vietnam and China: mini Singapores abroad. In Singapore the name of the game today is: added value at high aggregation. The country is the living proof that right policies produce the right results.

China, (the third economy in the world) by its sheer size and stage of development seems to be the opposite of Singapore, though they share a common language. Over the last 15 years the economy has been growing by an average of $10 \%$. It is estimated that China, within 25 years, will overtake the USA economy. From then on, it will be the largest economy of the world. The estimated industrial output today is US\$ 5 trillion ( USA today: $+/-7$ trillion) with an estimated future growth of at least $8 \%$ per annum.

The liberal economic policies, which were commenced by Deng Xiao Ping, have transformed the country almost overnight. Industrial output in the private sector counts for $60 \%$ of the total production and the participation of the state-owned companies is still declining. The most privatised entity is the army which today, is co-owner of more then 20,000 companies with a profit of US\$ 5 billion. They have to set hotels, Karaoke bars and their own transportation routes.

Chinese are very pragmatic as far as the economy goes. Many years ago, Deng Xiao Ping said: "it does not matter what the colour is of the cat, as long as it catches mice". It signalled the end of the official belief in communism as an economic system (or philosophy).

Less known and yet a very recognised multinacional economic power: the Overseas Chinese, called by Naisbitt the third largest economy of the world, a "network of networks". Some call it the bamboo network. It works more or less like Internet, bringing together tens of thousands of networks, a giant marketplace with a tremendous impact on the economic development not only of China, but of the whole Asia Pacific region and beyond.

Of course, China is not perfect, and there are big differences in wealth distribution throughout the country. The GDP in Shanghai is 5 times that of the interior of the country, with the coastal provinces in between. Until recently, millions of people died from famine; but today, economic growth is double digit and is counted also in building sites per city.

Latin America has not woken up to these new economic realities: Asia is becoming the most important economical powerhouse of the world. Within a few years time, the middle class alone will have a purchasing power of more than US $\$ 8$ trillion.

Here, for our future, we can no longer take a passive view of the movements of change and developments in Asia. Actually, we should become proactive, more knowledgeable about this region.

We should also look for business opportunities for Brazilian companies in this region. Also, we can learn from Asia the policies of the different countries and the way these are applied. It will help us to understand how we can better use our resources to attract capital and technology and how to open up new markets.

Asia Pacific is becoming essential to us for learning, for business and for our economic development. According to the Chinese belief, the next century will be the era of the Dragon. That is very much an eastern, Chinese symbol. It indicates the dominance of Asia Pacific, particularly, as an economic and political power for many years to come.

The British said it a long time ago: "Young man, go East". This is even more relevant today.

Singapore, December $5^{\text {th }}, 1996$.

Frans Sluiter foi Presidente da Philips do Brasil antes de assumir seu posto atual no comando da Philips Eletronics da Asia Pacific. No Brasil participou ativamente da vida da EAESP/FGV como membro do Conselho Administrativo, recebendo o título honorífico de Grande Benemérito.
The British

said it a long

time ago:

"Young man,

go Easf. This

is even more

relevant

today. 